\title{
Synthesis of novel Levulinic Acid based Poly(amine-co-ester)s
}

Yann Bernhard, ${ }^{\text {a }}$ Lucas Pagies, ${ }^{\text {a }}$ Sylvain Pellegrini, ${ }^{a}$ Till Bousquet, ${ }^{\text {a }}$ Audrey Favrelle, ${ }^{\text {a }}$ Lydie Pelinski, ${ }^{a}$ Pascal Gerbaux ${ }^{\mathrm{b}}$ and Philippe Zinck ${ }^{\mathrm{a}^{*}}$

Four novel biobased monomers (i.e. two diesters and two hydroxyesters) bearing a tertiary amine in their backbone have been synthesized from the sustainable methyl levulinate and amino-alcohol/amino-esters derived from natural amino-acids. Their homopolymerization / copolymerization with diols leads to six Poly(amine-co-Ester)s with various microstructures. These families of biodegradable polyesters have been reported to be efficient carriers for gene delivery. The polymers are carefully characterized by nuclear magnetic resonance spectroscopy $\left({ }^{1} \mathrm{H}\right.$ and $\left.{ }^{13} \mathrm{C} N M R\right)$, size exclusion chromatography (SEC), and exhibits molecular weight (Mn) up to $36 \mathrm{~kg}^{\mathrm{mol}}{ }^{-1}$ and dispersities $(E)$ between 1.5 and 2.1. They also present a good solubility in aqueous acidic media due to the amine protonation. Such properties are hopeful for applications in the biomedical field or in personal care products.

\section{Introduction}

In recent years, the growing interest in renewable resources has promoted the development of numerous biobased polymers for a wide range of applications. For instance, in the biomedical field, ${ }^{1-4}$ naturally occurring polysaccharides, like pectins, alginates, chitin have been used for surgical devices, tissue engineering and drug delivery. In particular, when interacting with the anionic plasmid DNA, ${ }^{5,6}$ cationic chitosan-based systems have emerged as non-viral and non-toxic gene delivery vectors. Alternatively, biodegradable and biocompatible polymeric particles of Poly(Lactic Acid) (PLA), Poly(Glycolic Acid) (PGA) or PolyButyleneSuccinate (PBS) have proven to be good candidates for drug encapsulation as well. In this context, due to their potential as nonviral carriers for DNA (or gene) delivery, polyesters containing amine functional groups in the main or side chain, have sparked a growing interest in the last decade. ${ }^{7-12}$ Like chitosan, their cationic properties display binding plasmid DNA, resulting in a polyelectronic complex (polyplex). In comparison with conventional amine-containing polymers, i.e. Poly(Ethylene-imine) or Poly(L-Lysine), it has been highlighted that the additional ester linkage allows for 1) a higher biodegradability, thus avoiding the accumulation of polymers in the body after repeated administration, 2) a lower cytotoxicity, and 3) an outstanding gene transfection efficiency.

Consequently, over the past three decades, several Poly(Amine-co-Ester)s (PAEs) have been prepared through various synthetic approaches. First examples have involved the polycondensation of $N$-protected amino-acids, by means of a coupling agent (DCC/DMAP) or a catalyst (APTS) and have led to poly(L-serine ester)s, ${ }^{13}$ poly (Laspartate ester)s, ${ }^{14}$ poly(4-hydroxy-L-proline ester), ${ }^{15,16}$ or Poly[R-(4-Aminobutyl)-L-Glycolic Acid] (PAGA) (Scheme 1.A). ${ }^{17}$ Another convenient, catalyst-free and easy to implement method is based on the poly-Michael addition of secondary or primary amines to bisacrylate derivatives (Scheme 1.B). This synthetic pathway furnished a large

\footnotetext{
a. Univ. Lille, CNRS, Centrale Lille, ENSCL, Univ. Artois, UMR 8181 - UCCS - Unité de Catalyse et Chimie du Solide, F-59000 Lille (France).E-mail: philippe.zinck@univlille.fr

b. Organic Synthesis \& Mass Spectrometry Laboratory, University of Mons - UMONS,

23 Place du Parc, B-7000 Mons, Belgium.E-mail: Pascal.GERBAUX@umons.ac.be

+Electronic Supplementary Information (ESI) available: Experimental details,

spectroscopic data, NMR, SEC and DSC spectra. See DOI: 10.1039/x0xx00000x
} 
library of Poly( $\beta$-aminoester)s possessing gene delivery or antibacterial properties. ${ }^{18-30}$ It is worth noting that these two first approaches $A$ and $B$ lead to relatively low molecular weight polymers. As an alternative, the ringopening polymerization (ROP) of amine-containing lactones is used to prepare PAEs. For such process, the amine moiety is present either in the backbone of the polymer when starting from protected-amine containing lactones, ${ }^{31-33}$ or in its side chain when starting from amine-substituted lactones (Scheme 1.C), ${ }^{34-38}$ or introducing by thiol-ene post modification. ${ }^{39}$ In addition, as outlined in Scheme 1.D, a classical approach consisting in the condensation of a diacid or a diester with an aminodiol is implemented to prepare PAEs for gene delivery applications. ${ }^{4-45}$ The diol precursor is generally a $\mathrm{N}$-alkylated $\mathrm{N}, \mathrm{N}$-diethanolamine. As the amino group can deactivate metal catalysts, this type of polycondensation is usually catalyzed by an enzyme. ${ }^{41,42}$ Asides from these polymerizations, a polycondensation between sebacoyl chloride and $\mathrm{N}$-methyldiethanolamine has also been reported for the synthesis of the poly( $N$-methyl diethyleneamine sebacate). ${ }^{46}$

\section{A. $N$-protected amino-acids}

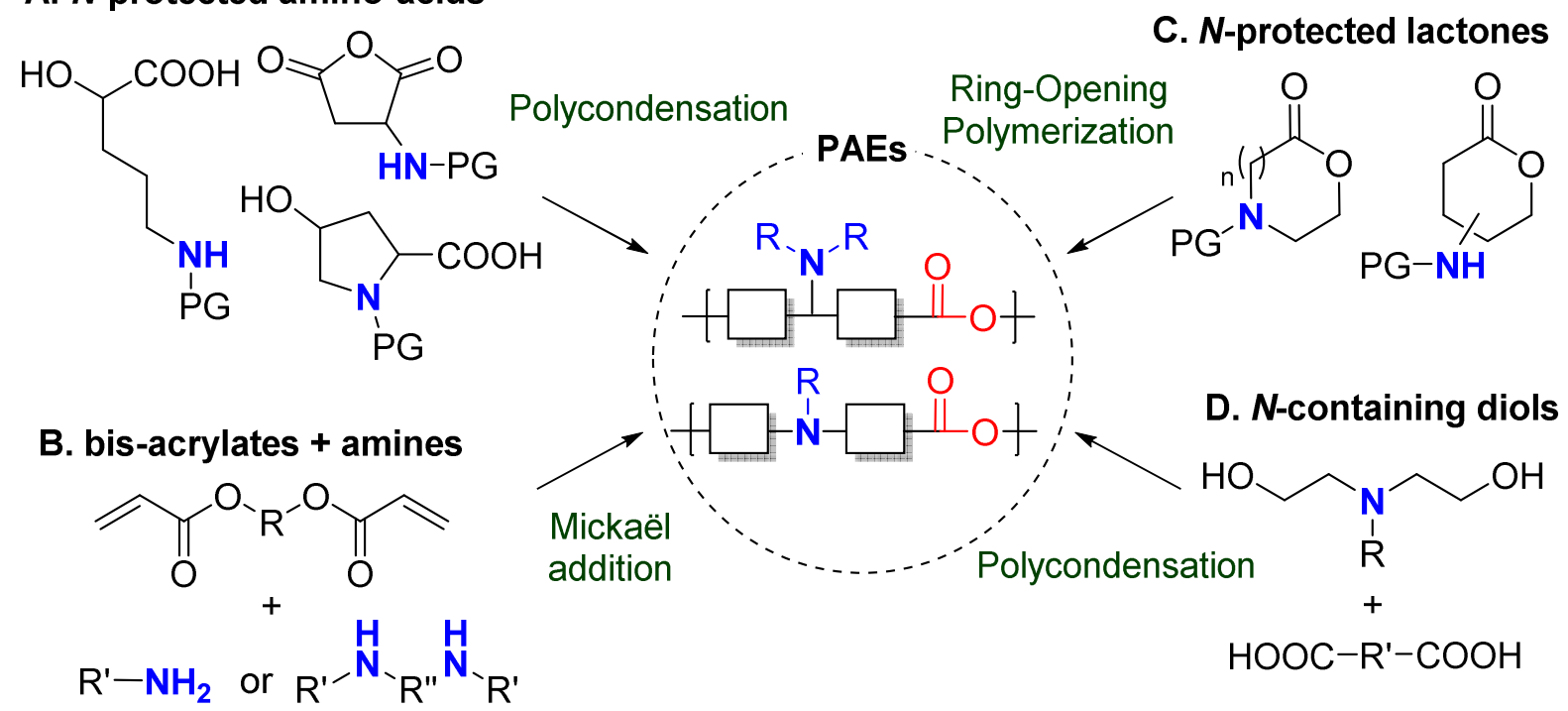

Scheme 1. Synthetic routes to Poly(Amine-co-Ester)s (PAEs).

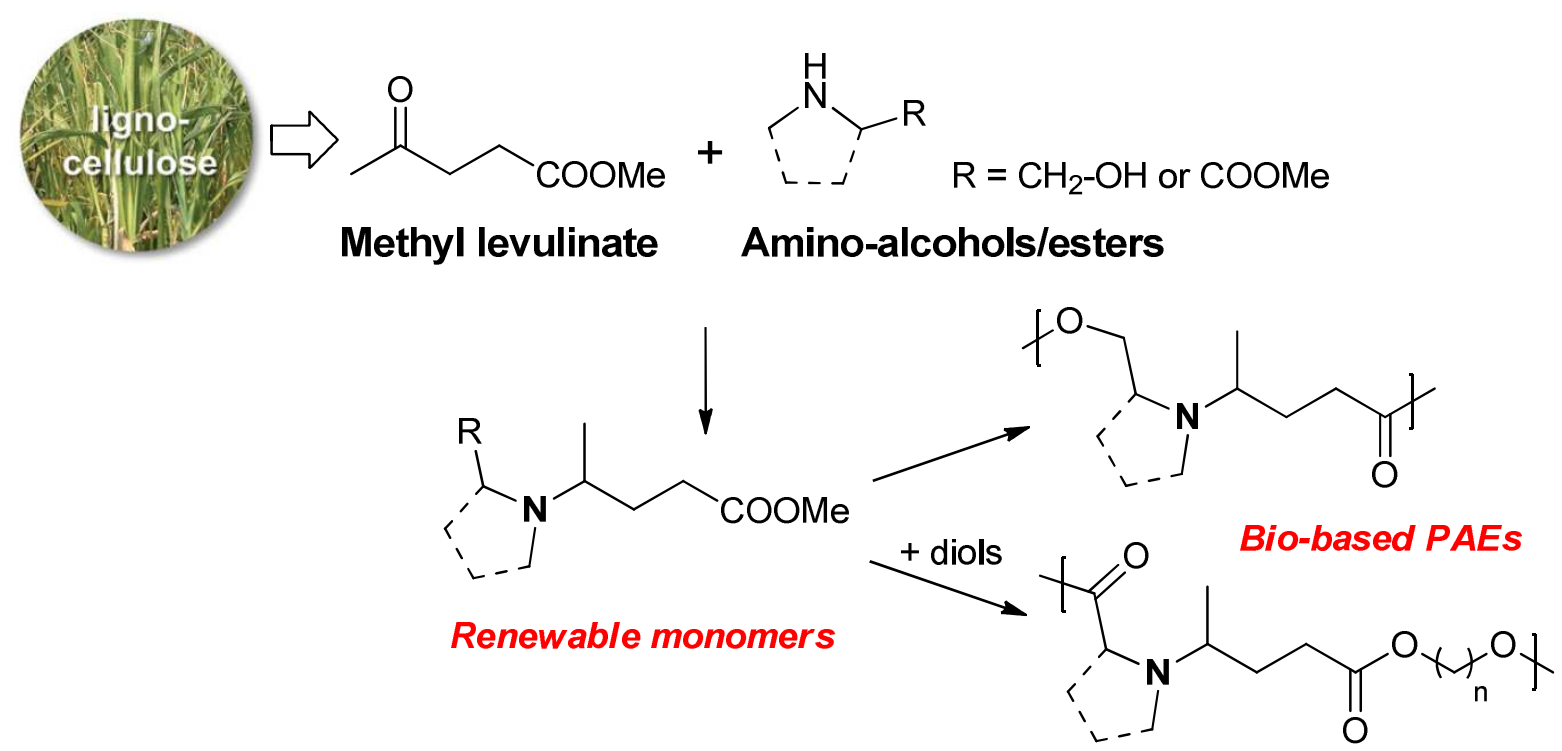

Scheme 2. The synthesis of bio-based PEAs from renewable monomers prepared from methyl levulinate and amino alcohols or amino esters. 
We wish to describe herein the synthesis of renewable PAE polymers from levulinic acid and amino acid derivatives (Scheme 2). To the best of our knowledge, this synthetic approach has not yet been investigated. Among bio-based building blocks, levulinic acid is one of the most promising and has been highlighted in the synthesis of various fine chemicals of interest. ${ }^{47-51}$ As an example, the reductive amination of levulinic acid with aliphatic or aromatic primary amines followed by a cyclization has been widely described to access bio-based solvents alternative to NMP ( $N$-MethylPyrrolidone). ${ }^{52}$ Besides this, amino acids and their derivatives are one the most important natural structural units found in many fine chemicals and polymers. As such, these structures occupy a prominent place in bio-based industry. ${ }^{55}$

\section{Experimental}

\section{Materials.}

Chemicals used in this study were purchased from standard suppliers and used as received. Solvents were dried by a MBRAUN Solvent Purification System (MB-SPS-800).

\section{Instrumentation.}

All reactions (synthesis of monomers) were monitored by GC-FID analysis on a Shimadzu GC-2014. ${ }^{1} \mathrm{H}$ NMR and ${ }^{13} \mathrm{C}$ NMR spectra were recorded in $\mathrm{CDCl}_{3}$ or $\mathrm{D}_{2} \mathrm{O}$ on a Bruker $\mathrm{AC} 300$ spectrometer at room temperature. High Resolution Mass Spectra (HRMS) were measured on a Waters Synapt G2-Si (mode ESI(+)) at the University of Mons, Belgium. The number-average molar masses $\left(M_{n}\right)$ and the polydispersity indexes $(\Theta)$ were determined by Size Exclusion Chromatography (SEC) in tetrahydrofuran at $40{ }^{\circ} \mathrm{C}$ with a flow rate of $1 \mathrm{~mL} \cdot \mathrm{min}^{-1}$. The $\mathrm{M}_{\mathrm{n}}$ and the $\oslash$ were derived from the Refractive Index (RI) signal with a calibration curve based on PolyStyrene (PS) standards from Polymer Standards Service. Thermal characterization of the polymers was performed with a DSC7 PerkinElmer instrument calibrated according to standard procedures using a high purity Indium sample. For the analyses, samples $\left(10 \mathrm{mg}\right.$ ) were placed into aluminum pans and heated from $-70^{\circ} \mathrm{C}$ to $180^{\circ} \mathrm{C}$ at a rate of 10 ${ }^{\circ} \mathrm{C} \cdot \mathrm{min}^{-1}$.

\section{General procedure for the synthesis of monomers.}

A $250 \mathrm{~mL}$ two-necked round-bottom flask was conditioned under argon atmosphere and charged with anhydrous dichloromethane $(100 \mathrm{~mL})$. Then, methyl levulinate $(3 \mathrm{~mL}, 24.2 \mathrm{mmol})$ and the appropriate amino-alcohol/aminoester $(36.3 \mathrm{mmol}$ ) were introduced into the flask, followed by potassium carbonate (for compounds $1 \mathrm{c}$ and $\mathbf{1 d}$ ) and sodium triacetoxyborohydride $(10.8 \mathrm{~g}, 50.9 \mathrm{mmol})$. The reaction mixture was stirred under argon atmosphere at room temperature and monitored by GC-FID analysis. When the conversion remains constant (48-72 h), $100 \mathrm{~mL}$ of $1 \mathrm{M}$ aqueous solution of $\mathrm{NaOH}$ were added to the reaction, and the two layers were separated. The aqueous layer was further extracted twice with $50 \mathrm{~mL}$ of dichloromethane, and the combined organic layers were dried with magnesium sulfate and concentrated under reduced pressure. The product was directly purified by distillation under a short-path vacuum distillation apparatus (Kugelrohr apparatus) and obtained as a colourless liquid.

\section{General procedure for the synthesis of polymers.}

The two-stage melt polycondensation was performed using a Kugelrohr apparatus. A $25 \mathrm{~mL}$ one-necked round bottom flask was charged with monomers $\mathbf{2 a - d}(0.5 \mathrm{~g})$ and diols (1 eq.) -for compounds $\mathbf{2 c}-\mathbf{d}$. After the catalyst ( $0.1 \mathrm{~mol} \%)$ was introduced, the flask was fitted with one Kugelrohr bulb to collect the methanol produced, and then connected to the Kugelrohr device. After purging the apparatus three times with argon, the temperature was first set at $180^{\circ} \mathrm{C}$ under an atmospheric pressure of Argon for 5 hours. During this period, methanol was distilled off and collected in the external bulb. The vacuum was slowly reduced to 0.2 mbar over a period of 30 $\min$. Then the mixture was left at $180^{\circ} \mathrm{C}$ for 8 hours. After cooled down to room temperature, the polymer was collected without any further purification and obtained as a viscous sticky solid. 


\section{Results and discussion}

Monomer synthesis.

Reductive aminations of ketones with secondary amines are well known to be more challenging than with primary amines. Therefore, to reduce the iminium/enamine intermediate, longer reaction times and smoother reducing agent are usually required. ${ }^{54}$ For this reason, we decided to perform the reductive amination of methyl levulinate (LevOMe) by sodium triacetoxyborohydride as the reducing agent.

As a result, the two aminohydroxyesters $\mathbf{2} \mathbf{a}$ and $\mathbf{2} \mathbf{b}$ were isolated from $\mathbf{N}$-methylaminoethanol $\mathbf{1 a}$ and L-prolinol $\mathbf{1 b}$ and the two aminodiesters $\mathbf{2} \mathbf{c}$ and $\mathbf{2} \mathbf{d}$ were obtained from sarcosine methyl ester $\mathbf{1} \mathbf{c}$ and L-proline methyl ester 1d hydrochloride salts. The reaction conditions and the results are summarized in Table 1 . The best conversions were obtained using dichloromethane (DCM) as the solvent and with an excess of reducing agent (1.5-2.1 eq.). As anticipated, several days of reaction time were required to reach an acceptable yield ( 2 to 3 days). Interestingly, cyclic L-prolinol $\mathbf{1} \mathbf{b}$ and L-proline ester $\mathbf{1} \mathbf{d}$ afforded the desired compounds $\mathbf{2} \mathbf{b}$ and $\mathbf{2} \mathbf{d}$ with higher yields (>85\%) than the linear amines with in addition lower reaction times and a lower amount of reducing agent (entries 2 and 4). Several other amino derivatives such as $N$-ethylaminoethanol, pipecolic acid methyl ester, $N, N^{\prime}-$

dimethylethylenediamine and piperazine were evaluated but failed to furnish PEA monomers in reasonable yields (Table S1). From these results, it can be assumed that the reductive amination reaction is mainly governed by steric hindrance factors. Monomers $\mathbf{2 a - d}$ were easily purified by distillation under reduced pressure and as such did not request the use of costly and non-green purification solvents.<smiles>COC(=O)CCC(C)C1CCCN1C(C)CCC(=O)OC</smiles>

Hydroxyesters:<smiles>CC(=O)CCC(C)N(C)CCO</smiles><smiles>CC(=O)CCC(C)N1CCC[C@H]1CO</smiles>

Diesters:<smiles>COC(=O)CN(C)C(C)CCC(C)=O</smiles>

Scheme 3. Synthesis of aminohydroxyesters (2a-b) and diesters (2c-d) from methyl levulinate (LevOMe) and amino-alcohol or amino-esters (1a-d). 
Table 1. Structure, conditions and yields for the synthesis of monomers $\mathbf{2 a - d}$ starting from methyl levulinate (LevOMe) and amino-alcohol/esters 1a-d (see Scheme 3).

\begin{tabular}{|c|c|c|c|c|c|}
\hline Entry & $1 a-d^{a}$ & Product & $\begin{array}{l}\text { STAB }^{b} \\
\text { (Eq.) }\end{array}$ & $t(h)$ & Yield $(\%)^{c}$ \\
\hline 1 & $\begin{array}{l}N \text {-methyl aminoethanol } \\
\text { (1a) }\end{array}$ & $2 a$ & 2.1 & 72 & 72 \\
\hline 2 & L-prolinol (1) & $2 b$ & 1.5 & 48 & 86 \\
\hline $3^{d}$ & Sarcosine methyl ester $(\mathbf{1} \mathbf{c})^{\mathrm{e}}$ & $2 c$ & 2.1 & 72 & 56 \\
\hline $4^{d}$ & L-proline methyl ester $(\mathbf{1} \mathbf{d})^{\mathrm{e}}$ & $2 d$ & 1.5 & 48 & 90 \\
\hline
\end{tabular}

[a] 1.5 eq of amine per mole of methyl levulinate, [b] STAB: Sodium TriAcetoxy Borohydride, [c] Isolated yield after purification by distillation under reduced pressure, [d] in presence of $\mathrm{K}_{2} \mathrm{CO}_{3}(1.5 \mathrm{Eq}$.), [e] Chlorohydrate form.

Interestingly, monomers $\mathbf{2} \mathbf{b}$ and $\mathbf{2 d}$, obtained from the enantiomerically pure L-prolinol and L-proline methyl ester respectively, were isolated as a mixture of two diastereomers with a 70/30 diastereomeric ratio. That is well highlighted on the ${ }^{1} \mathrm{H}-\mathrm{NMR}$ (Figure S11) and ${ }^{13} \mathrm{C}$-NMR (Figure S12) spectra of compound $\mathbf{2} \mathbf{d}$ where all signals are distinct.

\section{Polymer synthesis.}

Thereafter, the synthesis of PAE by the polycondensation of the renewable monomer $2 \mathrm{a}$ was investigated. A classical two step procedure was started by the oligomerization under argon during 4 hours following by the slow introduction of dynamic vacuum which was maintained for 8 hours at $180^{\circ} \mathrm{C}$ to remove the methanol byproduct. Table 2 gathers the yield, the number-average molecular weight $\left(M_{n}\right)$ and the dipersity $(\boxplus)$ measured by SEC analysis of the crude polymer, from a survey of nine different catalysts $(0.1 \mathrm{~mol} \%)$. A Brönsted base $\left(\mathrm{K}_{2} \mathrm{CO}_{3}\right)$, a Brönsted acid (paraToluene Sulfonic Acid, $p \mathrm{TsOH}$ ) and several Lewis acids, i.e. zinc (II), tin (II and IV), antimony (III) and titanium (II) derivatives were assessed. A low molar mass was obtained when the polymerization was conducted without any catalyst (entry 1 ). The Brönsted base led to higher molecular weight than the Brönsted acid, but both were outperformed by the metal-based Lewis acids. The use of dibutyltin dilaurate afforded a polymer with a molar mass of $14.8 \mathrm{~kg} \cdot \mathrm{mol}^{-1}$ (entry 6). Zinc acetate (entry 4) and antimony(III) oxide (entry 7), led in turn to oligomers. The best result was finally obtained with titanium(II) isopropoxyde (entry 8), giving the PEA-I in $70 \%$ yield, a Mn of $36 \mathrm{~kg}_{\mathrm{mol}} \mathrm{m}^{-1}$ and a dispersity $Ð$ of 1.9. Therefore, all other PEAs were synthesized using this catalyst. 
Table 2. Catalyst screening for the polymerization of hydroxyester $2 \mathrm{a}$ by a two-stage melt polycondensation.

\section{+ $0.1 \mathrm{~mol} \%$ Catalyst}<smiles>COC(=O)CCC(C)N(C)CCOc1ccccc1</smiles>

2a

PAE-I

\begin{tabular}{|c|c|c|c|c|}
\hline Entry & Catalyst & $\begin{array}{l}\text { Yield } \\
\text { (\%) }\end{array}$ & $\begin{array}{l}\mathrm{M}_{\mathrm{n}} \\
\left(\mathrm{kg} \cdot \mathrm{mol}^{-1}\right)^{\mathrm{a}}\end{array}$ & $\theta^{a}$ \\
\hline 1 & - & 29 & 1.2 & 1.1 \\
\hline 2 & $\mathrm{~K}_{2} \mathrm{CO}_{3}$ & 25 & 4.1 & 1.7 \\
\hline 3 & $p \mathrm{TsOH}$ & 43 & 2.1 & 1.5 \\
\hline 4 & $\mathrm{Zn}(\mathrm{OAc})_{2}$ & 75 & 2.3 & 1.7 \\
\hline 5 & $\mathrm{Sn}(\mathrm{Oct})_{2}$ & 50 & 5.7 & 1.9 \\
\hline 6 & $\mathrm{SnBu}_{2}$ (laurate) $)_{2}$ & 65 & 14.8 & 1.8 \\
\hline 7 & $\mathrm{Sb}_{2} \mathrm{O}_{3}$ & 65 & 2.7 & 1.7 \\
\hline 8 & $\mathrm{Ti}(\mathrm{OiPr})_{4}$ & 70 & 36.0 & 1.9 \\
\hline 9 & $\mathrm{Ti}(\mathrm{OBu})_{4}$ & 83 & 10.0 & 1.8 \\
\hline
\end{tabular}

[a] GPC in THF at R.T. vs. polystyrene standards.

The PEA-I was next characterized by proton (Figure S14) and carbon (Figure S15) NMR spectroscopy. The spectrum are fully ascribed using 2D NMR experiment (Figure S3). On the ${ }^{1} \mathrm{H}-\mathrm{NMR}$ spectrum, the transformation from monomer to polymeric material is highlighted by the disappearance of the signal of (i) the hydroxyl group at $2.93 \mathrm{ppm}$, (ii) the methyl ester at $3.58 \mathrm{ppm}$ and (iii) the methylene attached to the hydroxyl at $3.46 \mathrm{ppm}$. The new triplet at $4.09 \mathrm{ppm}$ corresponds to the methylene protons attached to the oxygen atom. On the ${ }^{13} \mathrm{C}-\mathrm{NMR}$ spectrum, the transformation is also assessed by the shift of the methylene carbons of the ethanolamine moiety.

Following the polymerization procedure described above, a series of six new bio-based poly(amine-co-ester)s, namely, PEA-I to PEA-VI was synthesized starting from monomers 2a-d. The results of the polycondensation are summarized in Table 3. As for PEA-I, the synthesis of PEA-II was performed in bulk, using titanium isopropoxyde as the catalyst. The yield and the dispersity were in range of the one obtained for PEA-I, with a lower molecular weight. The diesters $\mathbf{2} \mathbf{c}$ and $\mathbf{2} \mathbf{d}$ were co-polymerized with 1,4-butanediol and 1,6-hexanediol. This approach allows to play on the properties of the PEA, by adjusting the hydrophobicity and decreasing the positive charge density via the introduction of a hydrocarbon chain. Such modulations are highly desirable for gene delivery applications, as a reduced charge density leads to a decrease of the carrier's cytotoxicity. ${ }^{40}$ The polymers PEA-III and PEA-IV were obtained with $\mathrm{Mn}$ ranging from 3.2 to $11.5 \mathrm{~kg} \cdot \mathrm{mol}^{-1}$ and dispersities between 1.8 and 2.8 . 
The thermal properties of the PAEs were analyzed by DSC. All polymers were found to be amorphous. The glass transition temperature (Tg) is given in Table 3. The Tg of PAE-I is around

$-40^{\circ} \mathrm{C}$. The introduction of a rigid cycle in the polymer backbone led to a significant increase of $50^{\circ} \mathrm{C}$ of the glass transition temperature of PAE-II vs. PAE-I. The effect was less pronounced for PEA-V and PEA-VI vs. PEA-III and PEA-IV, respectively, probably due to the increased chain mobility of the diol co-monomer. Regarding the influence of the latter, it can be seen that 1,6-hexanediol based PAEs led to lower glass transition temperature that 1,4-butanediol based ones.

\section{Protonation experiments.}

To highlight the potential of these polymers as gene carrier or their use in personal care products, the water solubility in acidic aqueous media was assessed. On the proton spectrum of PEA-I in $\mathrm{D}_{2} \mathrm{O}$ containing $5 \%$ of deuterated trifluoroacetic acid (TFA-d) (Figure S38), it can be noticed that the signals of the protons close to the protonated nitrogen are shifted to higher ppm values. Moreover, the protonation of the nitrogen resulted in the creation of a new stereogenic center, and so led to diastereomers. This is consistent with the multiplicity observed for the signals of the protons close to the asymmetric carbon/nitrogen centers. This water solubility in acidic media was also observed for the more hydrophobic polymers PEA-II-VI.

\section{Conclusion}

We report the synthesis of four new bio-based amino-containing monomers of PEA from renewable methyl levulinate and aminoalcohol or aminoesters, via an exclusive reductive amination promoted with good yields. New bio-based PEAs were further synthesized by polycondensation of these new monomers, i.e homopolymerisation of the hydroxyesters or copolymerisation of the diesters with butanediol and hexanediol, leading to number-average molecular weight up to $36 \mathrm{~kg} \cdot \mathrm{mol}^{-1}$. A study of the dilution of the cationic charge allowed us to adjust the hydrophobicity of the carrier. Therefore, this methodology offers an opportunity to synthesize water-soluble PAEs from renewable resources and with tunable properties for gene delivery applications.

\section{Acknowledgements}

This work was funded by the FWV ALPO Interreg Grant and the authors thanks the European Regional Development Fund (FEDER) and the University of Lille. Chevreul Institute (FR 2638), Ministère de l'Enseignement Supérieur et de la Recherche, Région Hauts de France are also acknowledged for supporting and funding partially this work. The authors are gratefully acknowledged to Aurélie Malfait for GPC measurements. The UMONS laboratory thanks the FRS-FNRS (Fonds pour le Recherche Scientifique) for financial support for the acquisition of the Waters Synapt G2-Si mass spectrometer. 
Table 3. Structure, yields and properties of the six synthesized PEAs.

\begin{tabular}{llllll} 
Polymer & Yield (\%) & $\mathrm{Mn}\left(\mathrm{kg} \cdot \mathrm{mol}^{-1}\right)^{\mathrm{a}}$ & $\theta^{a}$ & $\left.\mathrm{~T}_{\mathrm{g}}{ }^{\circ} \mathrm{C}\right) \mathrm{b}$ \\
\hline PAE-I & 70 & 36.0 & 1.9 & -40 \\
PAE-II & 72 & 14.1 & 2.1 & 11 \\
PAE-V & 85 & 3.2 & 2.2 & -40 \\
PAE-III & 90 & 5.5 & 1.8 & -46 \\
\end{tabular}

[a] GPC in THF at R.T. vs. polystyrene standards. [b] Determined by DSC on the second heating curve 


\section{Notes and references}

1 K. M. Zia, A. Noreen, M. Zuber, S. Tabasum, M. Mujahid, Int. J. Biol. Macromol. 2016, 82, 1028.

2 T. Garrison, A. Murawski, R. Quirino, Polymers 2016, 8, 262.

3 E. D. Bartzoka, C. Crestini, H. Lange, in Handb. Polym. Pharm. Technol. (Eds.: V.K. Thakur, M.K. Thakur), John Wiley \& Sons, Inc., Hoboken, NJ, USA, 2015, 127.

4 R. P. Babu, K. O'Connor, R. Seeram, Prog. Biomater. 2013, 2, 8.

5 M. Köping-Höggård, I. Tubulekas, H. Guan, K. Edwards, M. Nilsson, K. Vårum, P. Artursson, Gene Ther. 2001, 8, 1108.

6 B. J. Patel, N. K. Vignesh, G. Hortelano, World J. Med. Genet. 2016, 6, 22.

7 [7] J. Luten, C. F. van Nostrum, S. C. De Smedt, W. E. Hennink, J. Controlled Release 2008, 126, 97.

8 M. A. Mintzer, E. E. Simanek, Chem. Rev. 2009, 109, 259.

9 H. Seyednejad, A. H. Ghassemi, C. F. van Nostrum, T. Vermonden, W. E. Hennink, J. Controlled Release 2011, $152,168$.

10 Y.-J. Gao, Z.-Y. Qiao, H. Wang, Sci. China Chem. 2016, 59, 991.

11 R. B. Arote, D. Jere, H.-L. Jiang, Y.-K. Kim, Y.-J. Choi, M.-H. Cho, C.-S. Cho, Mater. Technol. 2010, 25, 196.

12 Y.-K. Kim, C. Zhang, C.-S. Cho, M.-H. Cho, H.-L. Jiang, in Novel Gene Therapy Approaches (Eds.: W. Ming, D. Good), IntechOpen, $2013,375$.

13 Q. X. Zhou, J. Kohn, Macromolecules 1990, 23, 3399.

14 C.-Y. Won, C.-C. Chu, T.-J. Yu, Macromol. Rapid Commun. 1996, 17, 653.

15 D. Putnam, R. Langer, Macromolecules 1999, 32, 3658.

16 Y. Lim, Y. H. Choi, J. Park, J. Am. Chem. Soc. 1999, 121, 5633.

17 Y. Lim, C. Kim, K. Kim, S. W. Kim, J. Park, J. Am. Chem. Soc. 2000, 122, 6524.

18 W. Cheng, D. Wu, Y. Liu, Biomacromolecules 2016, 17, 3115.

19 D. M. Lynn, R. Langer, J. Am. Chem. Soc. 2000, 122, 10761.

20 G. González, X. Fernández-Francos, À. Serra, M. Sangermano, X. Ramis, Polym. Chem. 2015, 6, 6987.

21 J. Ko, K. Park, Y.-S. Kim, M. S. Kim, J. K. Han, K. Kim, R.-W. Park, I.-S. Kim, H. K. Song, D. S. Lee, I. C. Kwon, J. Controlled Release 2007, 123, 109.

22 J. J. Green, R. Langer, D. G. Anderson, Acc. Chem. Res. 2008, 41, 749.

23 Z.-Y. Qiao, S.-L. Qiao, G. Fan, Y.-S. Fan, Y. Chen, H. Wang, Polym. Chem. 2013, 5, 844.

24 R. Arote, T.-H. Kim, Y.-K. Kim, S.-K. Hwang, H.-L. Jiang, H.-H. Song, J.-W. Nah, M.-H. Cho, C.-S. Cho, Biomaterials 2007, $28,735$.

25 D. M. Lynn, D. G. Anderson, D. Putnam, R. Langer, J. Am. Chem. Soc. 2001, 123, 8155.

26 A. Akinc, D. M. Lynn, D. G. Anderson, R. Langer, J. Am. Chem. Soc. 2003, 125, 5316.

27 Y. Liu, D. Wu, Y. Ma, G. Tang, S. Wang, C. He, T. Chung, S. Goh, Chem. Commun. 2003, 60, 2630.

28 J. J. Green, J. Shi, E. Chiu, E. S. Leshchiner, R. Langer, D. G. Anderson, Bioconjug. Chem. 2006, 17, 1162.

29 D. G. Anderson, D. M. Lynn, R. Langer, Angew. Chem. Int. Ed. 2003, 42, 3153.

30 G. T. Zugates, D. G. Anderson, S. R. Little, I. E. B. Lawhorn, R. Langer, J. Am. Chem. Soc. 2006, 128, 12726.

31 M. Trollsås, V. Y. Lee, D. Mecerreyes, P. Löwenhielm, M. Möller, R. D. Miller, J. L. Hedrick, Macromolecules 2000, 33, 4619.

32 N. L. Benner, K. E. Near, M. H. Bachmann, C. H. Contag, R. M. Waymouth, P. A. Wender, Biomacromolecules 2018, 19, 2812.

33 C. J. McKinlay, J. R. Vargas, T. R. Blake, J. W. Hardy, M. Kanada, C. H. Contag, P. A. Wender, R. M. Waymouth, Proc. Natl. Acad. Sci. 2017, 114, E448.

34 J. Hao, S. Elkassih, D. Siegwart, Synlett 2016, 27, 2285.

35 Z. Hu, Y. Chen, H. Huang, L. Liu, Y. Chen, Macromolecules 2018, 51, 2526.

36 S. Blanquer, J. Tailhades, V. Darcos, M. Amblard, J. Martinez, B. Nottelet, J. Coudane, J. Polym. Sci. Part Polym. Chem. 2010, 48, 5891.

37 J. Hao, P. Kos, K. Zhou, J. B. Miller, L. Xue, Y. Yan, H. Xiong, S. Elkassih, D. J. Siegwart, J. Am. Chem. Soc. 2015, $137,9206$.

38 B. Nottelet, M. Patterer, B. François, M.-A. Schott, M. Domurado, X. Garric, D. Domurado, J. Coudane, Biomacromolecules 2012, $13,1544$.

39 V. Darcos, S. Antoniacomi, C. Paniagua, J. Coudane, Polym Chem 2012, 3, 362.

40 J. Zhou, J. Liu, C. J. Cheng, T. R. Patel, C. E. Weller, J. M. Piepmeier, Z. Jiang, W. M. Saltzman, Nat. Mater. $2012,11,82$.

41 J. Liu, Z. Jiang, J. Zhou, S. Zhang, W. M. Saltzman, J. Biomed. Mater. Res. A 2011, 96A, 456.

42 Z. Jiang, Biomacromolecules 2010, 11, 1089.

43 X. Zhang, W. Tang, Z. Yang, X. Luo, H. Luo, D. Gao, Y. Chen, Q. Jiang, J. Liu, Z. Jiang, J. Mater. Chem. B 2014, 2, 4034.

44 I. Voevodina, M. Scandola, J. Zhang, Z. Jiang, RSC Adv. 2014, 4, 8953.

45 J. Chen, W. Jiang, H. Han, J. Yang, W. Chen, Y. Wang, J. Tang, Q. Li, ACS Macro Lett. 2017, 6, 523.

46 Y. Wang, L.-S. Wang, S.-H. Goh, Y.-Y. Yang, Biomacromolecules 2007, 8, 1028.

47 J. J. Bozell, G. R. Petersen, Green Chem. 2010, 12, 539.

48 L. T. Mika, E. Cséfalvay, Á. Németh, Chem. Rev. 2017,118, 505.

49 I. Delidovich, P. J. C. Hausoul, L. Deng, R. Pfützenreuter, M. Rose, R. Palkovits, Chem. Rev. 2016, 116, 1540.

50 F. H. Isikgor, C. R. Becer, Polym. Chem. 2015, 6, 4497.

51 K. Yan, C. Jarvis, J. Gu, Y. Yan, Renew. Sustain. Energy Rev. 2015, 51, 986.

52 L. Yan, Q. Yao, Y. Fu, Green Chem. 2017, 19, 5527.

53 C. O. Tuck, E. Perez, I. T. Horvath, R. A. Sheldon, M. Poliakoff, Science 2012, 337, 695.

54 A. F. Abdel-Magid, K. G. Carson, B. D. Harris, C. A. Maryanoff, R. D. Shah, J. Org. Chem. 1996, 61, 3849. 